\title{
CHARACTERISTIC OF DEMAND AND SUPPLY OF ACCESSIBLE TOURISM IN MORAVIAN-SILESIAN REGION
}

\author{
[Charakteristika poptávkové a nabídkové strany př́istupného turismu $\mathrm{v}$ \\ Moravskoslezském kraji]
}

Dagmar Zorková ${ }^{1}$

\author{
${ }^{1}$ Slezská univerzita, Obchodnè podnikatelská fakulta, Univerzitní nám. 1934/3, 73340 Karviná \\ Email:dagmar.zorkova@fpf.slu.cz
}

\begin{abstract}
This article deals with the issue of accessible tourism. The objective of the article is to describe current situation of demand and supply of accessible tourism in Moravian-Silesian region, to use secondary data analysis and primary research results. The demand is characterized by market potential, number of overnight stays per year, opinions of potential clients on dimension of accessibility. The supply is characterized by accommodation capacities, including barrier-free accommodation, and service providers' views of accessibility.
\end{abstract}

Keywords: accessible tourism, barrier-free accommodation capacity, market potential, research.

JEL classification: L83

Doručeno redakci: 10.6.2016; Recenzováno: 27.6.2016;4.7.2016; Schváleno k publikování: 19.10.2016

Úvod

Dle demografických odhadů dosáhne v roce 2025 podíl evropské populace starší 65 let téměř $35 \%^{1}$. Generace seniorů se bude stávat velice podstatným segmentem, což bude přinášet praktické důsledky pro mnohé aspekty turismu. Na tento trend reaguje př́stupný turismus, jehož výchozí podmínkou je př́istupnost budov a prostředí. Jak zdůrazňují Neumann, Reuber et al. (2004), př́ístupnost se v průběhu života stává důležitou pro každého. Autoři uvádějí, že u zastavěného prostředí je zásadním požadavkem pro $10 \%$ populace, nutností pro 30 - $40 \%$ populace a podmínkou pohodlí pro $100 \%$ populace.

V České republice se jedná o poměrně novou problematiku, z tohoto důvodu je cílem článku vyhodnocení aktuální situace poptávkové a nabídkové strany př́istupného turismu v Moravskoslezském kraji. Úvod článku se věnuje vymezení pojmů a teoretických východisek, následuje metodika práce a charakteristika poptávkové a nabídkové strany v Moravskoslezském kraji.

\section{Problematika př́ístupného turismu}

\subsection{Vymezení pojmů}

Stárnutí obyvatelstva znamená pro turismus nárůst počtu klientů, jež uvítají během cestování prŕstupné prostředí. Myšlenka př́istupnosti vychází z filozofie „design for all“, jedná se o takový př́stup k plánování a realizaci zastavěného prostředí, výrobků a služeb, jež umožňuje podílet se na životě v komunitě všem osobám. Jak uvádějí Darcy, Cameron a Pegg (2010), „univerzální design“ je řadou světových autorů považován za paradigma, rozšiřující pojetí kontinuálních cest, př́stupnosti a mobility a bezbariérového prostředí, včetně začlenění

\footnotetext{
${ }^{1}$ Webový portál Evropské komise: Final report: Mapping and Performance Check of the Supply of Accessible Tourism Services. [online][vid. 15. ůnora 2016]. 2015. Dostupné z:

$<$ http://www.accessibletourism.org/?i=enat.en.reports.1740 >.
} 
mezigeneračního plánování, které uznává spojitost mezi stárnutím, postižením a vývojem schopnostmi lidí v průběhu jejich života.

Generální tajemník UNWTO² poukazuje na roli přístupného turismu jakožto ústředního prvku každé odpovědné a udržitelné politiky turismu. Autoři Buhalis a Darcy (2011) jej považují za cestovní ruch zahrnující a vyžadující spolupráci všech zúčastněných stran, jejímž výsledkem je univerzálně navržený turistický produkt, služby a prostředí, které umožňují lidem se specifickými požadavky na př́stupnost, samostatnou, rovnoprávnou a důstojnou účast na turismu. Česká společnost Kazuist (2010) vyzdvihuje důležitost jednoduchého př́ístupu k zařízením, stavbám, dopravě, informacím, komunikacím, atrakcím a jiným službám v destinaci a to včetně aktivního zapojení všech klientů do programů a akcí pro hosty.

Potenciální klient se specifickými potřebami očekává prř́stupnost komplexní nabídky napříč celým řetězcem turistických služeb v destinaci. Př́istupnost služeb je tvořena dimenzemi:

- fyzická př́istupnost (tzv. bezbariérovost budov a prostředí, dopravy, infrastruktury),

- informační přístupnost (spolehlivost informací, přístupné komunikační kanály, standardy pro posuzování př́stupnosti),

- komunikační přístupnost (chování personálu ke klientům a způsob komunikace s nimi),

- $\quad$ ekonomická př́ístupnost (výběr z různých cenových úrovní).

Nejvýznamnějšími segmenty potenciálních zákazníků př́istupného turismu jsou osoby ve věku nad 65 let, osoby se zdravotním postižením a osoby doprovázející děti do tří let ${ }^{3}$.

\subsection{Teoretická východiska}

Autoři Buhalis a Darcy (2011) pohlížejí na přístupný turismus jako na fenomén, který se určitým způsobem vyvíjí nejen v oblasti akademických studií, ale i v odvětvové praxi. Dimenze tohoto fenoménu jsou multidisciplinární a zasahují do geografie, studií o zdravotním postižení, ekonomie, veřejné politiky, psychologie, sociální psychologie, managementu, postmoderních kulturních studií, marketingu, architektury, medicíny a dalších.

Výchozí studie problematiky př́stupnosti v turismu se zabývají modely procesů. Buhalis a Darcy (2011) aplikují v modelu fungování systému turismu a př́stupnosti konceptuální př́stup, přičemž zdůrazňují, že tuto problematiku je důležité vnímat jak z pohledu medicínského (individuálního), tak současně i sociálního. Packer, Mckercher a Yau (2007) rozšiŕili konceptuální prŕístup o dimenzi životního prostředí a na základě studia osobních a environmentálních faktorů navrhli šesti-stupňový model a stanovili předpoklady, za kterých je pro potenciálního turistu možné procházet jednotlivými stupni až k aktivnímu cestování. $\mathrm{V}$ současné post-moderní společnosti dochází v sociálním modelu k výrazným změnám, $\mathrm{v}$ důsledku kterých je podle Shawa a Colese (2003) cestování stále rychlejší. Vlivem tohoto zrychlení se zvyšuje komprese času a prostoru, což působí na osoby se specifickými potřebami jako deprimující faktor.

Na aktuálnosti nabývá propojení problematiky př́stupnosti se sociální odpovědností a udržitelností turismu. Darcy, Cameron a Pegg (2010) zkoumají ve své studii koncept

\footnotetext{
${ }^{2}$ Webový portál UNWTO: UNWTO approves accessible tourism recommendations. [online][vid. 10. března 2016]. Dostupné z: <http://media.unwto.org/press-release/2013-09-/unwto-approves-accessible-tourismrecommendations $>$.

${ }^{3}$ Dále se jedná např. o osoby $\mathrm{s}$ akutním úrazem znemožňujícím pohyb, $\mathrm{s}$ chronickým nemocněním, onemocněním vnitřních orgánů, obézní, malého nebo nadměrného vzrůstu, osoby s objemnými zavazadly apod.
} 
př́stupného turismu a jeho spojení s tříúrovňovou základnou udržitelnosti (triple-bottomline TBL scorecard), se zaměřením na finance, životní a sociální prostředí. Tento rámec bere na vědomí stále rostoucí důraz na udržitelnost v oblasti cestovního ruchu a současně zájem podniků o růst a finanční úspěch.

Výzkumy poptávkové strany př́istupného turismu, tedy zjišt’ování zákaznických potřeb a chování, patří mezi nejčastěji publikované práce. Figueiredo, Eusébio a Kastenholz (2012) zkoumali diference mezi segmenty portugalských turistů, týkající se cestovatelského chování, vyplývající $\mathrm{z}$ jednotlivých druhů postižení. Identifikovali důležité rozdíly v mobilitě, omezeních a úrovni samostatného zvládání situací. Výsledky výzkumu australského autora Darcyho (2010) poskytují detailnější pochopení spotřebitelských potřeb v ubytovacích službách, kde autor navrhuje zavést nový systém sběru a prezentace aktuálních a efektivních informací. Informační potřeby osob se zdravotním postižením a prř́slušné technické obtíže spojené s jejich řešením zkoumal výzkum Michopoulou a Buhalise (2013). Závěry ukazují nutnost holistických informací o prŕstupnosti v rámci destinace. V evropském prostoru sehrává podstatnou úlohu Závěrečná zpráva Evropské komise (2014), která se zabývá demografickou situací, cestovatelským chováním, ekonomickými př́nosy a doporučeními pro další rozvoj přístupného turismu. Pro srovnání byly vybrány studie, které byly provedeny v Německu a v Moravskoslezském kraji a to jednak z důvodu geografické, ale také sociálněkulturní srovnatelnosti respondentů. Situaci v Německu popisují Neumann et al. (2004), více než polovina cílového trhu je tvořena zákazníky staršími 65 let, přičemž demografický vývoj způsobí, že počet těchto osob výrazně vzroste a současně průměrná délka jejich dovolené je delší. Respondenti cestují nezávisle na ročním období a vysoký podíl dovolených tráví v Německu. V Moravskoslezském kraji zkoumala tuto problematiku studie Bezbariérový cestovní ruch společnosti Kazuist. Svým rozsahem a výsledky je tato studie v České republice ojedinělá a její závěry o zákaznickém chování se v podstatě shodují se závěry německé studie, podstatný rozdíl je však ve finanční situaci dotazovaných (zkrácené výsledky studie viz príloha 1).

Výzkumem nabídkové strany přístupného turismu v Evropě se zabývá Závěrečná zpráva Evropské komise (2015), která mapuje nabídku př́stupných turistických služeb prostřednictvím Informačního systému prístupnosti (AIS) a navrhuje praktiky a nástroje pro praxi turismu.

\section{Metodika}

Následující kapitola vymezuje metodiku práce, seznamuje s výzkumnými otázkami a designem obou výzkumů a metodikou výpočtu tržního potenciálu.

\subsection{Výzkum poptávkové strany př́ístupného turismu}

Tematicky se výzkum zabýval specifikací poptávkové strany př́istupného turismu.

Obecná výzkumná otázka: Jaké jsou požadavky a názory potenciálních klientů př́stupného turismu?

\section{Design výzkumu}

Metoda: šetření typu Survey

Výběr vzorku: kombinace kvótního výběru (vycházející ze statistického rozdělení jednotlivých segmentů v základním souboru České republiky a v Moravskoslezském kraji) a úsudkového výběru (dotazování byli respondenti, kteří cestují)

Způsob sběru dat, nástroj: osobní dotazování, dotazník pro řízený rozhovor 
Rámec výběrového souboru: do výběrového souboru byly vybrány tři nejvýznamnější segmenty potenciálních klientů: senioři, osoby se zdravotním postižením a osoby doprovázející děti do tří let Specifikace výběrového souboru probíhala dle následujících kontrolních znaků:

- $\quad$ senioři, 610 osob - demografické kritérium,

- osoby se zdravotním postižením, 340 osob - kritérium typ postižení (fyzické zrakové, sluchové, mentální),

- osoby doprovázející děti, 265 osob - demografické kritérium (věk dítěte do tř́ let). Celkový počet respondentů činil 1215 osob.

\section{Realizace výzkumu}

Osobní dotazování formou řízeného rozhovoru bylo primárně zaměřeno na osoby, které cestují a probíhalo v Moravskoslezském kraji (Ostrava, Opava a okolí) v měsících leden a únor 2014.

\subsection{Výzkum nabídkové strany př́stupného turismu}

Tematicky se výzkum zabýval specifikací nabídkové strany př́stupného turismu.

Obecná výzkumná otázka: Jak hodnotí poskytovatelé služeb turismu problematiku př́stupnosti?

\section{Design výzkumu}

Metoda: šetření typu Survey

Výběr vzorku: kombinace kvótního a úsudkového výběru

Způsob sběru dat, nástroj: osobní dotazování, dotazník pro řízený rozhovor

Rámec výběrového souboru: do výběrového souboru bylo vybráno pět typů subjektů, poskytujících služby v turismu: stravovací zařízení, informační centra, turistické atraktivity, cestovní kanceláře, ubytovací zařízení.

Specifikace výběrového souboru probíhala dle následujících kontrolních znaků:

- př́slušnost do jednoho z pěti typů subjektů - v rámci každého typu bylo vybráno dvanáct provozoven, což celkově činí 60 provozoven,

- $\quad$ velikost či návštěvnost subjektu - předpoklad, že větší či více navštěvované subjekty mají lepší zdroje na vytváření podmínek pro klienty se specifickými potřebami a že o ně mají zájem.

Celkově se jednalo o vzorek šedesáti respondentů.

\section{Realizace výzkumu}

Osobní dotazování formou řízeného rozhovoru s manažerem či pracovníkem subjektu turismu probíhalo v Moravskoslezském kraji (Ostrava, Opava a okolí) od ledna 2014 do dubna 2015.

Souhrn výsledků statistického testu je umístěn v př́loze 3.

\subsection{Metodika výpočtu tržního potenciálu př́ístupného turismu v MSK}

Výpočet velikosti potenciálního trhu v Moravskoslezském kraji (dále jen MSK) vychází z postupu Kotlera (2007), Q = n . q · p, a z následujících předpokladů:

- v uvedených segmentech cestuje 68,8 \% osob se zdravotním postižením (dále jen Ozp), $60 \%$ osob nad 65 let (dále jen On65) (zdroj: studie Kazuist 2012),

- průměrná denní útrata činí u jednodenních cest $450 \mathrm{Kč}$, jedná se o průměr uváděné částky a částky, kterou jsou cestující ochotni utratit (zdroj: studie Kazuist 2012),

- průměrná denní útrata činí u vícedenních cest 1515 Kč u Ozp a 1753 Kč u On65 (zdroj: Závěrečná zpráva Evropské komise 2014), 
- počet dnů strávených na jednodenních cestách je 7,9 u Ozp a 8,7 dnů u On65 (zdroj: Závěrečná zpráva Evropské komise 2014),

- počet dnů strávených na vícedenních cestách je 7,1 u Ozp a 8 dnů u On65 (zdroj: Závěrečná zpráva Evropské komise 2014),

- $\quad$ vzhledem k tomu, že se studie Evropské komise nezabývá skupinou osob doprovázející děti, není tato skupina zařazena do výpočtu (údaje o cestovatelském chování této skupiny neexistují).

\section{Charakteristika poptávkové strany př́stupného turismu v Moravskoslezském kraji} Poptávková strana prŕstupného turismu je charakterizována prostřednictvím výpočtu velikosti tržního potenciálu, poptávaným počtem přenocování a výsledky výzkumu názorů potenciálních klientů na dimenze prístupnosti.

\subsection{Tržní potenciál př́ístupného turismu v MSK}

Celkový počet osob v Moravskoslezském kraji, jež vyžadují př́stupnost je 393966 jak uvádí tabulka 1. Ve výpočtu velikosti potenciálního trhu v MSK byla využita Závěrečná zpráva Evropské komise a studie Kazuistu.

Tabulka 1: Počet osob v segmentech př́stupného turismu v MSK

\begin{tabular}{|l|l|}
\hline Segment př́stupného turismu & Počet osob v MSK \\
\hline Osoby nad 65 let & \\
\hline Osoby se ZP & 207466 \\
\hline Osoby doprovázející děti & 125238 \\
\hline Celkem & 61262 \\
\hline
\end{tabular}

Poznámka: údaje za rok 2013.

Zdroj: ČSÚ: Obyvatelstvo Krajské ročenky [online][vid. 15. února 2016]. Dostupné z <http:// /www.czso.cz/csu/czso/krajske-rocenky>.

Tabulka 2: Cestovatelské chování klientů přístupného turismu v MSK

\begin{tabular}{|l|l|l|l|l|}
\hline & \multicolumn{2}{|c|}{ Osoby zp } & \multicolumn{2}{c|}{ Osoby nad 65 let } \\
\cline { 2 - 5 } & Cesta 1 den & Cesta vícedenní & Cesta 1 den & Cesta vícedenní \\
\hline $\begin{array}{l}\text { Počet osob, které } \\
\text { cestují }\end{array}$ & 86164 & 86164 & 124480 & 124480 \\
\hline Počet dnů/rok & 7,9 & 7,1 & 8,7 & 8 \\
\hline $\begin{array}{l}\text { Prüměrné denní } \\
\text { výdaje (Kč) }\end{array}$ & 450 & 1515 & 450 & 1753 \\
\hline
\end{tabular}

Zdroj: Závěrečná zpráva Evropské komise (2014), studie Kazuist (2012)

Tabulka 2 obsahuje údaje o cestovatelském chování, z nichž je vypočtena velikost potenciálního trhu v MSK, který celkově pro oba segmenty činí 3 466, 203 mil Kč, jak je patrné z tabulky 3 .

${ }^{4}$ V ČR je ve věkové skupině 60 -74 let podíl osob zdravotně postižených 19,37\% a ve věkové skupině 75 a více let je tento podíl 41,88 \%. Tato skutečnost však zde není, vzhledem k neaktuálnosti zdroje, rozdílnému rozdělení do věkových skupin a absenci údajů pro MSK, brána v úvahu (zdroj: Výsledky šetření o zdravotně postižených osobách v ČR za rok 2007. Odbor statistik rozvoje společnosti ČSÚ ve spolupráci s ÚZIS. Dostupné z: <http://www.nrzp.cz/dokumenty/Vybrane_statisticke_udaje_OZP_2007.pdf) >.

${ }^{5}$ Pro MSK byla prioritně použita data ze studie Kazuistu, jež se však nezabývala průměrnou denní útratou u vícedenních cest a počtem dnů strávených na jednodenních a vícedenních cestách. Z tohoto důvodu jsou údaje čerpány ze Závěrečné zprávy EK. 
Tabulka 3: Tržní potenciál př́stupného turismu v MSK

\begin{tabular}{|l|l|l|l|l|}
\hline \multirow{2}{*}{} & \multicolumn{2}{|c|}{ Osoby ZP } & \multicolumn{2}{c|}{ Osoby nad 65 let } \\
\cline { 2 - 5 } & Cesta 1 den & Cesta vícedenní & Cesta 1 den & Cesta vícedenní \\
\hline $\begin{array}{l}\text { Tržní potenciál } \\
\text { (mil. Kč) }\end{array}$ & 306,313 & 926,823 & 487,359 & 1745,708 \\
\hline
\end{tabular}

Tržní potenciál celkem MSK (mil. Kč)

Zdroj: Vlastní výpočet

\subsection{Počet poptávaných přenocování za rok}

Záměrem charakteristiky poptávkové a nabídkové strany př́istupného turismu je také srovnání aktuální situace v poptávce a nabídce po př́stupném ubytování v MSK. Počet přenocování, který je poptáván ilustruje tabulka 4.

Tabulka 4: Počet poptávaných přenocování v MSK/rok

\begin{tabular}{|l|l|l|}
\hline & $\begin{array}{l}\text { Ozp } \\
\text { cesta vícedenní }\end{array}$ & $\begin{array}{l}\text { On65 } \\
\text { cesta vícedenní }\end{array}$ \\
\hline $\begin{array}{l}\text { Počet osob, které } \\
\text { cestují }\end{array}$ & 86164 & 124480 \\
\hline Počet nocí/rok & 6 & 7 \\
\hline Počet přenocování & 516984 & 871360 \\
\hline
\end{tabular}

\begin{tabular}{|l|l|}
\hline $\begin{array}{l}\text { Počet poptávaného přenocování } \\
\text { celkem }\end{array}$ & 1388344 \\
\hline
\end{tabular}

Zdroj: Vlastní výpočet

Rozsah poptávaného přenocování v rámci prrístupného turismu činí u segmentu osob zdravotně postižených 516984 přenocování a u segmentu osob nad 65 let 871360 přenocování. Celkově u obou segmentů se jedná o 1388344 přenocování.

\subsection{Výzkum názorů potenciálních klientů}

Cílem výzkumu byla deskripce názorů potenciálních klientů přístupného turismu. Do výběrového souboru byly zařazeny osoby nad 65 let věku (610), osoby se zdravotním postižením (340) a osoby doprovázejících děti do 3 let (265), tedy tři nejvýznamnější segmenty. Celkový počet respondentů činil 1215 osob.

V článku jsou uvedeny výsledky odpovědí na otázky, které se týkaly dimenzí prístupnosti. Respondenti vyjádřili také své náměty na zlepšení a inovace, jejichž počet činil u seniorů 1 229, u zdravotně postižených osob 729 a u osob doprovázející děti 745. Vzhledem k velkému počtu odpovědí jsou nejčetnější či nejzajímavější z nich umístěny v prŕíloze 2.

\section{Dimenze 1: Bezbariérová př́ístupnost}

Obrázek 1 ilustruje důležitost odstranění tzv. tvrdých bariér. Je zřejmé, že senioři, osoby zdravotně postižené i osoby doprovázející děti považují za nejdůležitější, aby objekt disponoval výtahem, dále bezbariérovým vstupem a WC, poté označeným bezbariérovým parkovištěm. Pokud v objektu nejsou tvrdé bariéry odstraněny, způsobují turistům největší problémy, některým skupinám dokonce zcela znemožňují cestování. 
Obrázek 1: Důležitost odstranění tzv. tvrdých bariér

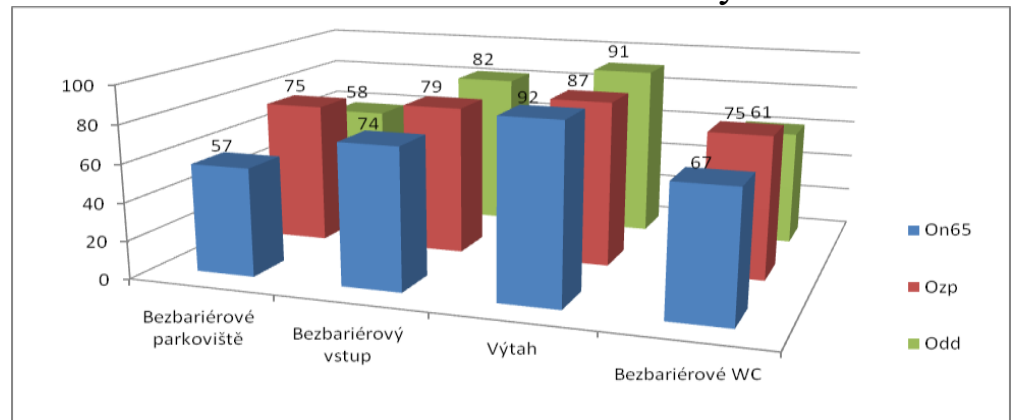

Zdroj: Vlastní výzkum (2014)

\section{Dimenze 2: Informační přístupnost}

Výzkum zjišt'oval znalost databáze společnosti Kazuist, která obsahuje seznam zmapovaných ubytovacích a stravovacích zařízení, turistických cílů a tras, včetně popisu a fotografií o bezbariérovosti. Její znalost potenciálními uživateli je však pouze 17 \%, jak prezentuje obrázek 2.

Obrázek 2: Znalost databáze klienty

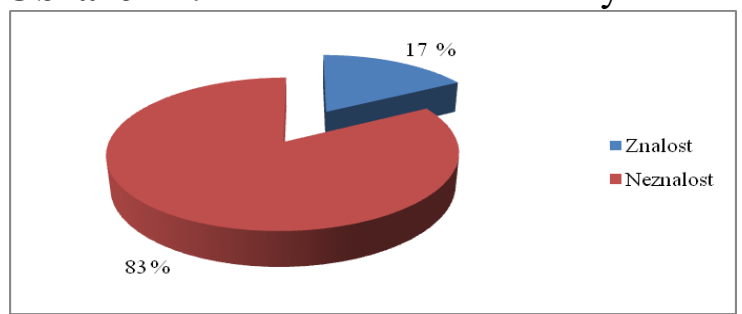

Zdroj: Vlastní výzkum (2014 - 2015)

\section{Dimenze 3: Komunikační př́ístupnost}

Předpokladem adekvátní komunikace personálu s klienty je proškolení v problematice. Potenciální klienti vyslovili názor, že proškolení personálu v komunikaci napomůže ke zvýšení kvality v 93 \% odpovědí, jak je patrné z obrázku 3.

Obrázek 3: Vliv proškolení personálu na kvalitu služeb

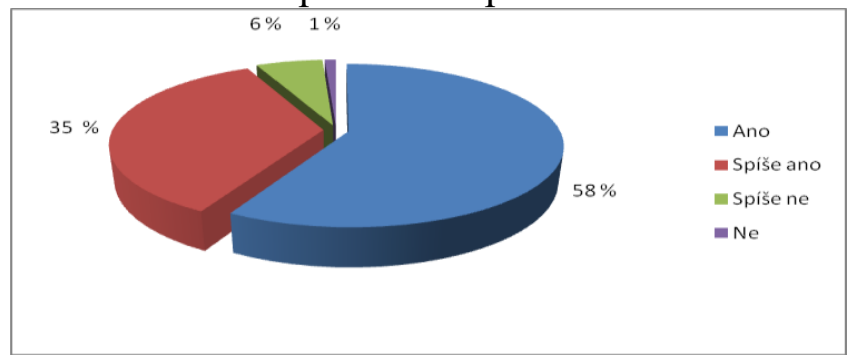

Zdroj: Vlastní výzkum (2014)

Školení by mělo být zaměřeno na zlepšení komunikace s klientem (29 \%), informovanost o konkrétních specifických potřebách klienti̊ (27\%), nutnost osobního př́stupu (25\%) a na praktický nácvik chování v konkrétních situacích (17\%). Ve variantě odpovědi jiné $(2 \%)$ se vyskytovaly následující náměty: ochota, zvládání stresových situací, trpělivost, základy znakové řeči. 


\section{Charakteristika nabídkové strany př́stupného turismu v MSK}

Nabídková strana přístupného turismu je charakterizována prostřednictvím kapacity ubytovacích služeb, nabízeného počtu přenocování a výsledků výzkumu názorů poskytovatelů služeb na dimenze př́stupnosti.

\subsection{Kapacita ubytovacích služeb}

Dle ČSÚ 6 je v Moravskoslezském kraji evidováno 569 hromadných ubytovacích zařízení, ve kterých je k dispozici 11559 pokojů, což představuje 29456 lůžek. Požadavky na bezbariérové užívání staveb jsou zakotveny ve Vyhlášce č 398/2009 Sb. ze dne 5. listopadu 2009, podle níž v ubytovacích zařízeních pro cestovní ruch musí nejméně $5 \%$ pokojů splňovat specifikované požadavky na bezbariérovost. Bezbariérových pokojů v MSK by tedy mělo být $5 \%$, což představuje 578 pokojů, skutečný stav se však může od tohoto čísla lišit.

Pro zjištění počtu ubytovacích zařízení, jejichž př́stupnost je garantována ${ }^{7}$ jsou využity existující databáze www.jedemetaky.cz a webové stránky cestovních kanceláŕí Atis a Bezbatour, jak je uvedeno v tabulce 5 (stav k 20. únoru 2016).

Tabulka 5: Počet bezbariérových ubytovacích zařízení s garancí v MSK

\begin{tabular}{|l|l|}
\hline Databáze & \\
\hline www.jedemetaky.cz & $\begin{array}{l}\text { Počet ubytovacích zařízení } \\
\text { s garantovanou př́istupností }\end{array}$ \\
\hline CkAtis & 23 \\
\hline CK Bezbatour & 6 \\
\hline Celkem & 0 \\
\hline
\end{tabular}

Zdroj: Vlastní průzkum (www.jedemetaky.cz, www.bezbatourcz, www.atis.cz)

\subsection{Počet nabízených přenocování za rok}

Pro srovnání aktuální situace v poptávaném a nabízeném počtu přenocování př́istupného turismu v MSK je následujícím postupem vypočten počet přenocování na straně nabídky:

počet nabízeného přenocování $=$ počet pokojů x průměrný počet lůžek v pokoji x počet dnů $\mathrm{v}$ roce $=548522$

Nabízený počet přenocování tedy činí $584582^{9}$ přenocování.

\subsection{Výzkum názorů poskytovatelů služeb turismu}

Cílem výzkumu byla deskripce názorů poskytovatelů služeb turismu na problematiku př́stupnosti. Do výběrového souboru bylo vybráno vždy 12 provozoven z pěti typů subjektů: stravovací zařízení, informační centra, turistické atraktivity, cestovní kanceláře, ubytovací zařízení. Celkově dotazování probíhalo v 60 zařízeních turismu.

\section{Dimenze 1: Bezbariérová přístupnost}

Za bezbariérovou byla pro účely výzkumu považována budova s bezbariérovým vstupem, společnými prostory, bezbariérovou toaletou, výtahem, popř. pokojem. Budovu vlastní provozovny považuje za bezbariérovou $81 \%$ respondentů, jak je patrné z obrázku 4 . Realizaci bezbariérových úprav však plánuje pouze jedna $\mathrm{z}$ oslovených provozoven.

\footnotetext{
${ }^{6}$ Webový portál ČSÚ: Kapacita hromadných ubytovacích zařízení dle krajů. [online] [vid. 15. února 2016]. Údaje pro rok 2014. Dostupné z: < https://www.czso.cz/csu/czso/krajske-rocenky\#10a>.

${ }^{7}$ Garance spočívá v posuzování bezbariérovosti pracovníky, vyškolenými v používání příslušné metodiky.

${ }^{8}$ Každé ubytovací zařízení je započítáno jednou, tzn. databáze se nepřekrývají.

${ }^{9}$ Jedná se o variantu, která vychází z počtu lůžek. Další varianta výpočtu vychází z počtu pokojů.

Počet přenocování (lůžka) = počet pokojů x průměrný počet lůžek v pokoji x počet dnů v roce $=548522$

Počet přenocování $($ pokoje $)=$ počet pokojů x počet dnů v roce $=210970$
} 
Obrázek 4: Bezbariérovost budovy provozovny

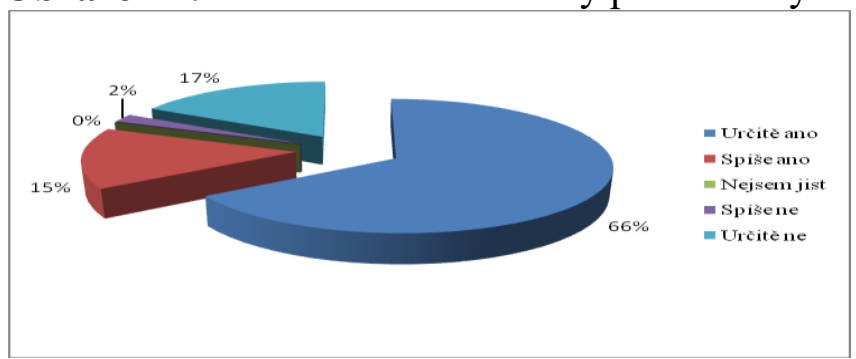

Zdroj: Vlastní výzkum (2014 - 2015)

\section{Dimenze 2: Informační přístupnost}

Poskytovatelé služeb znají databázi www.jedemetaky.cz ve stejném rozsahu jako klienti, jak vyplývá z obrázku 5. Zájem o zařazení do databáze mělo $60 \%$ oslovených subjektů.

Obrázek 5: Znalost databáze poskytovateli služeb

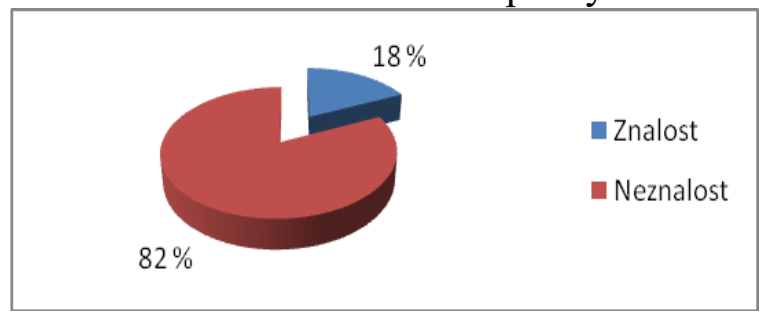

Zdroj: Vlastní výzkum (2014 - 2015)

\section{Dimenze 3: Komunikační př́stupnost}

Výsledky hodnocení adekvátnosti komunikace personálu byly překvapující, $93 \%$ poskytovatelů považuje komunikace za adekvátní, jak je patrné z obrázku 6. Domnívala jsem se, že pracovníci ve službách turismu si nejsou zcela jisti, jak se chovat ke klientům se specifickými potřebami. Tento můj předpoklad se potvrdil v otázce na potřebu školení, ve které $41 \%$ dotázaných uvedlo, že má zájem o proškolení v této problematice. Přričemž čtyři respondenti by byli za školení ochotni uhradit částku do 3000 Kč, ostatní mají o školení zájem pouze $\mathrm{v}$ případě hrazení $\mathrm{z}$ jiných zdrojů. Náplň školení by se měla týkat praktických ukázek a modelových situací v prostorech konkrétního pracoviště.

Obrázek 6: Adekvátnost komunikace personálu s klienty

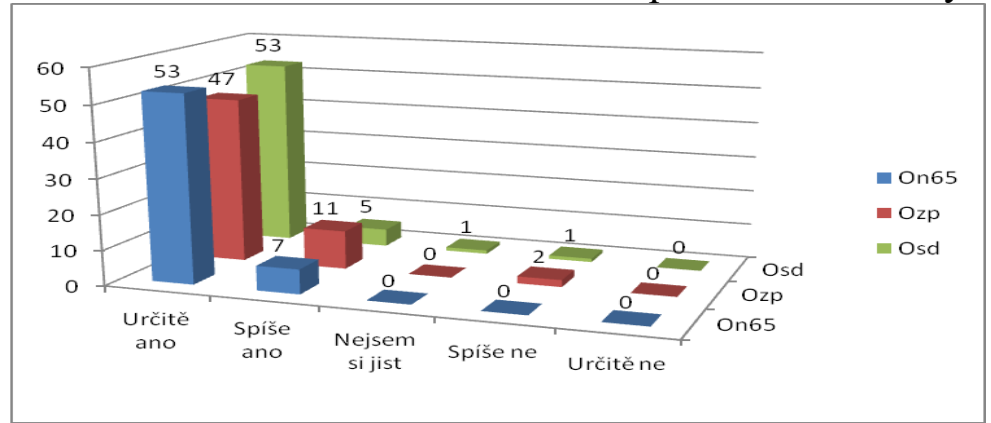

Zdroj: Vlastní výzkum (2014 - 2015) 


\section{Srovnání počtu přenocování na straně poptávky a nabídky v MSK}

V předchozích kapitolách byl vypočten roční počet poptávaného a nabízeného bezbariérového přenocování. Počet přenocování ${ }^{10}$ na straně poptávky ${ }^{11}$ činí u segmentu Ozp 516984 přenocování a u segmentu On65 let 871360 přenocování, což je celkově 1388344 přenocování. Kapacita přenocování na straně nabídky činí 584582.

Ze srovnání počtu přenocování na straně poptávky a na straně nabídky vyplývá, že kapacita nabídky bezbariérového ubytování zhruba odpovídá poptávce osob zdravotně postižených (kapacita na straně nabídky převyšuje poptávku o 77598 přenocování). Z pohledu př́stupného turismu však není vytvořena kapacita pro bezbariérové ubytování osob nad 65 let věku, tedy pro početně nejvýznamnější segment ${ }^{12}$ přístupného turismu.

\section{Závěr}

Cíle článku, tedy vyhodnocení aktuální situace poptávkové a nabídkové strany př́stupného turismu v MSK, bylo dosaženo. Na základě cestovatelského chování dvou segmentů př́stupného turismu byla vypočítána velikost tržního potenciálu př́ístupného turismu v Moravskoslezském kraji, jež činí 3 466,203 mil Kč. Ze srovnání počtu poptávaného a nabízeného bezbariérového přenocování za rok vyplynulo, že kapacita nabídky bezbariérového ubytování zhruba odpovídá poptávce segmentu osob zdravotně postižených. Z hlediska prŕstupného turismu však není vytvořena kapacita pro bezbariérové ubytování segmentu seniorů. Domnívám se, že zde je do budoucna prostor pro zvyšování kapacity bezbariérového ubytování, ovšem v takové kvalitě, která bude atraktivní nejen pro segmenty př́istupného turismu, ale také pro celkovou populaci.

Výše uvedenému zjištění odpovídají i výsledky výzkumů, z nichž je zjevné, že názory potenciálních klientů a poskytovatelů služeb se liší. Klienti se domnívají, že existují značné rezervy pro zlepšení služeb. Na druhé straně poskytovatelé považují nabídku svých služeb dostatečně uzpůsobenou klientům se specifickými potřebami. Rozdíly v odpovědích poukazují na velký potenciál v oblasti zlepšování kvality turistických služeb. Srovnatelné výsledky prezentují němečtí autoři Neumann, Reuber et al. (2004), kteří uvádějí, že $37 \%$ respondentů posuzuje př́istupnost turistických zařízení v Německu jako nedostatečnou a $48 \%$ z nich uvedlo, že by cestovali častěji, za předpokladu vyšší př́ístupnosti služeb. Autoři v závěrečném doporučení zdůrazňují, že odstranění překážek bránících cestování povede ke zvýšení intenzity cest a k větší poptávce po př́istupném turismu.

Poptávka po cestování bez ohledu na věk a zdravotní stav bude mít nepochybně rostoucí tendenci. Jak destinace, tak provozovatelé turistických služeb budou nuceni reagovat na tento sílící vývojový trend, analyzovat svou zákaznickou perspektivu a nabídnout segmentům zákazníků se specifickými potřebami odpovídající služby, což pro ně v důsledku může znamenat významnou konkurenční výhodu.

\section{Literatura}

[1] BUHALIS, D. and S. DARCY, 2011. Accessible Tourism: Concepts and Issues, UK, Bristol: Chanel View Publications. ISBN 978-1-84541-161-9.

[2] DARCY, S., B. CAMERON and S. PEGG, 2010. Accessible tourism and sustainability: discussion and case study. Journal of Sustainable tourism [online]. 18, 515-537 [vid 10.

\footnotetext{
${ }^{10}$ Jednotkou množství je počet přenocování/rok (tzv. člověkonoc)

${ }^{11}$ Odhad poptávky po přenocování ex ante

${ }^{12}$ Stejně tak pro třetí významný segment - rodiny s dětmi do 3 let a ostatní segmenty.
} 
ledna 2016]. ISSN 0966-9582. Dostupné Z: search.proquest.com/docview/365474380/2A5F612CBD4C02PQ/1? accountid=16966

[3] DARCY, S., 2010. Inherent complexibility: Disability, accessible tourism and accommodation informatik preferences. Information and Management [online]. 31, 816826 [vid 5. července 2016]. Dostupné z: www.sciencedirect.com/science/article/pii/S0261517709001642

[4] EVROPSKÁ KOMISE, 2014. Final report: Ekonomic Impact and Travel Patterns in Europe [online]. [vid. 10. února 2016]. Dostupné z: www.accessibletourism.org/?i=enat.en.enat_projects_and_good_practices.1407

[5] EVROPSKÁ KOMISE, 2015. Final report: Mapping and Performance Check of the Supply of Accessible Tourism Services [online]. [vid. 15. ůnora 2016]. Dostupné z: www.accessibletourism.org/? $\mathrm{i}=$ enat.en.reports.1740

[6] FIGUEIREDO, E., C. EUSÉBIO and E. KASTENHOLZ, 2012. How Diverse are Tourists with Disabilities? A Pilot Study on Accessible Leisure Tourism Experiences in Portugal. International journal of tourism research [online]. 14, 531-550 [vid 5. července 2016] Dostupné $\mathrm{Z:}$ onlinelibrary.wiley.com/doi/10.1002/jtr.1913/abstract?userIsAuthenticated=false\&denied AccessCustomisedMessage $=$

[7] JAKUBÍKOVÁ, D., 2012. Marketing v cestovním ruchu. Praha: Grada. ISBN 970-80247-4209-0.

[8] KAZUIST spol. s r.o. EUROPEAN NETWORK FOR ACCESSIBLE TOURISM (ENAT), NÁRODNÍ RADA OSOB SE ZDRAVOTNÍM POSTIŽENÍM ČR, TRIANON o. s., 2010. Athena na cestách. Př́stupný cestovní ruch v kostce. Třinec, (CZ 1.04/5.1.01/12.00018)

[9] KOTLER, P., V. WONG, J. SAUNDERS a G. ARMSTRONG, 2007. Moderni marketing. 4. evropské vydání. Praha: Grada Publishing. ISBN 978-80-247-1545-2.

[10] MICHOPOULOU, E. and D. BUHALIS, 2013. Information provision for challenging markets: The case of the accessibility requiring market in the context of tourism. Information and Management [online]. 50, 229-238 [vid. 3. června 2016]. Dostupné z: search.proquest.com/docview/1368262091/DEA38B18F254EFDPQ/1 ?accountid=16966

[11] NEUMANN, P., P. REUBER et al., 2004. Economic Impulses of Accessible Tourism for All. Study commissioned by the Federal Ministry of Economics and Labour. BMWA Berlin, Germany [online]. [vid. 11. března 2016]. ISSN 0342-9208. Dostupné z: www.bmwi.de/.../economic-impulses-of-accessible-tourism

[12] PACKER, L. T., B. McKERCHER and K. M. YAU, 2007. Understanding the complex interplay between tourism, disability and environmental contexts. Disability and Rehabilitation. Informa Healthcare [online]. 29(4), 281-292 [vid. 28. února 2016]. Dostupné z: informahealthcare.com/toc/dre/29/4

[13] SHAW, G. and T. COLES, 2004. Disability, holiday making and the tourism industry in the UK: a preliminary survey. Tourist management [online]. 25, 397-403 [vid. 3. ledna 2016]. Dostupné Z: www.sciencedirect.com/science/article/pii/S0261517703001390 


\section{Př́lohy}

\section{Př́loha 1}

\section{Průzkum společnosti Kazuist}

Cílem průzkumu mezi potenciálními uživateli byla analýza nákupního chování a rozhodování, ze které vyplynulo, že nejčastěji cestují senioři bez zdravotního omezení, těhotné ženy nebo osoby s malými dětmi a osoby se zrakovým postižením (přičemž cestuje $68,8 \%$ osob se zdravotním postižením, 60 \% osob nad 65 let a 88,8 \% osob s dětmi). Hlavním důvodem je relaxace a návštěva př́buzných a známých, upřednostněno je cestování s doprovodem, nezávisle na sezoně, s hlavním podílem domácího $\mathrm{CR}$, pouze desetina respondentů vnímá Moravskoslezský kraj z hlediska př́stupnosti infrastruktury jako přivětivější než ostatní regiony, denní útrata se pohybuje nejčastěji do 300 Kč, více než čtvrtina respondentů je však ochotna utratit do $600 \mathrm{Kč}$. Více než dvě třetiny využívají během pobytu stravovacích služeb, pořadí preferencí dopravních prostředků vede automobil, autobus a vlak.

\section{Př́loha 2}

\section{Připomínky a náměty potenciálních klientů (výzkum poptávkové strany přístupného} turismu)

\section{Dimenze 1: bezbariérová př́ístupnost}

- dostupnost MHD, vláčky, možnost svozu, zábradlí, eskalátory, více laviček, odpočívadel a toalet, turistické stezky pro seniory a handicapované, prostor pro vozíky,

- madla (WC, koupelna, postel), výška a polohovatelnost postele a zdravotní matrace, sprchy a protiskluzová podlaha, prostornost pokoje, výška nábytku a světelných vypínačů, otevírání oken, bezpečnost v pokoji,

- $\quad$ výška stolu pro podjetí vozíku, dostatečný prostor kolem stolů, možnost odložení berlí.

\section{Dimenze 2: informační přístupnost}

- $\quad$ kvalitnější značení, přehlednější informační tabule, větší písmo,

- informace v Braillově písmu, zvukový původce u atraktivit, hmatové exponáty,

- $\quad$ speciální či obrázkový jídelní lístek.

\section{Dimenze 3: komunikační přístupnost}

- ochota, erudovanost a př́ijemnost personálu,

- osobní a vstríícný př́stup,

- tlumočnické služby a orientace personálu v komunikaci s neslyšícím.

\section{Př́loha 3}

Hodnoty intervalu spolehlivosti

Vzorec: $\pi=P \pm 1,96 \sqrt{\mathrm{P}(1-\mathrm{P}) / \mathrm{n}}$

Důležitost odstranění tzv. tvrdých bariér

\begin{tabular}{|l|l|l|l|l|}
\hline & Parkoviště & Vstup & Výtah & WC \\
\hline On65 & $3,9 \%$ & $3,5 \%$ & $2,2 \%$ & $3,7 \%$ \\
\hline Ozp & $4,6 \%$ & $4,3 \%$ & $3,6 \%$ & $4,6 \%$ \\
\hline Odd & $6,0 \%$ & $4,6 \%$ & $3,5 \%$ & $5,9 \%$ \\
\hline
\end{tabular}

Vliv proškolení personálu na kvalitu služeb

\begin{tabular}{|l|l|l|l|l|}
\hline & Ano & Spíše ano & Spíše ne & $\mathrm{Ne}$ \\
\hline Celkem & $2,8 \%$ & $2,7 \%$ & $1,3 \%$ & $0,6 \%$ \\
\hline
\end{tabular}


Bezbariérovost budovy provozovny

\begin{tabular}{|l|l|l|l|l|}
\hline & Určitě ano & Spíše ano & Spíše ne & Určitě ne \\
\hline Celkem & $2,7 \%$ & $2,0 \%$ & $0,8 \%$ & $2,1 \%$ \\
\hline On65 & $3,8 \%$ & $2,8 \%$ & \multirow{2}{*}{} \\
\cline { 1 - 3 } Ozp & $5,0 \%$ & $3,9 \%$ & & \\
\cline { 1 - 2 } Odd & $5,7 \%$ & $4,3 \%$ & & \\
\cline { 1 - 2 }
\end{tabular}

Z t-testu mezi hodnotami získanými pro On65, Ozp a Odd (pro p = $95 \%$ ) vyplývá, že při dané hodnotě intervalu spolehlivosti jsou zjištěné výsledky u jednotlivých skupin statisticky nevýznamné (výzkum poptávkové strany).

Při počtu 60 respondentů byla odhadnuta přípustná chyba měření, která činí 3,7 \% (u jednotlivých segmentů On65 2,6 \%, Ozp 2,6 \% a Odd $3 \%$ ), z čehož plyne, že rozdíl mezi nimi je nevýznamný (dimenze 3 , výzkum nabídkové strany). 